\title{
Economic Integration and Security in the Middle East and North Africa: What prospects for a liberal peace?
}

\author{
Imad El-Anis ${ }^{1}$ \\ Nottingham Trent University \\ ${ }^{1}$ Corresponding Author: Imad El-Anis, Department of Politics and International Relations, \\ Nottingham Trent University, Burton Street, Nottingham, NG1 4BU, UK, Tel: +44 115 8483247, email: \\ imad.el-anis@ntu.ac.uk
}

\begin{abstract}
Since the late 1980s governments in the Middle East and North Africa (MENA) have created commercial institutions in order to promote regional economic integration. The primary aim of this policy has been regarded as the promotion of economic welfare gains at the national level. A second, albeit less-emphasized goal, has been to promote regional peace through economic interdependence. This study examines the prospects for a liberal peace in the MENA by analyzing two stages of the commercial institutional peace. Firstly, the study considers whether commercial institutions have promoted intra-regional trade in the MENA. Secondly, it examines if economic interaction has had an impact on promoting peace within the region. Twenty states are considered here and the unit of analysis is the dyad-year over a 25-year period from 1990-2014. This study finds that commercial institutions in the MENA have only a limited positive correlation with trade volume and while there is a direct positive correlation between economic integration and peace in the region, this is quite limited. These findings suggest that the conclusions made by previous studies that demonstrate a direct positive correlation between commercial institutions (and economic integration more generally) and peace, may be less applicable to some regions such as MENA.
\end{abstract}

Keywords: Commercial Institutional Peace, Middle East, North Africa, Economic Integration, Peace. 


\section{Economic Integration and Security in the Middle East and North Africa: What are the prospects for a liberal peace?}

Since the late 1980s many governments in the Middle East and North Africa (MENA) have adopted policies aimed at integrating their national economies with the broader global economy as well as with each other in order to promote domestic economic welfare gains (Fakhri, 2010; Galal and Hoekman, 2003; Hakimian and Nugent, 2005; Hoekman and Messerlin, 2002). A second aim has been to promote regional peace through economic interdependence and political cooperation (Gross and Sagi, 2000; Kilchevsky, 2007; Momani, 2007). The impact of these policies on promoting trade within the region, and their impact on regional peace, is not yet understood. Yet understanding how to promote peace in the region is perhaps more pressing now than at any time in the post-Cold War era (Davidson 2013). The region faces a myriad of security challenges including the rise of extremism, proxy wars at the regional level, and the negative effects of climate change. Furthermore, the region continues to play a major role globally, with regional security issues having a clear destabilizing effect on neighboring regions and the global hydrocarbon market.

Commercial institutional ${ }^{2}$ peace (from hereon, referred to as CIP) theory is used in this study in order to assess the impact of national trade policies, and the impact of economic integration on regional peace. The underlying thesis of this theory is that commercial institutions help to promote peace between states by increasing economic interdependence between trading partners (Oneal and Russett, 1999). This approach has developed since the 1990s, but has its limitations and needs further development. For example, CIP analyses tend to consider all states in the global system and apply generalizable conclusions to all regions and states equally. Yet, a deeper analysis of the impacts of commercial institutions and trade in the MENA (and other regions) may reveal a different story about the ways in which trade influences state behavior. This study tests the validity of the CIP theory in the context of the MENA, and investigates if trade influences peace and security in inter-state relations in the region. Like previous studies that have analyzed the relationship between economic integration, interdependence and political cooperation/peace (see: Barbieri, 1996; Copeland, 1996; Gartzke et al., 2001; Kanafani, 2001: Bearce, 2003; Oneal et al., 2003; McDonald, 2004; Goldsmith, 2013) this study has clear policy implications for current and future political leaders in the MENA and elsewhere.

This study considers the prospects for a liberal peace in the MENA by analyzing two separate but inter-connected stages of the CIP. Firstly, the study explores whether commercial institutions in the

\footnotetext{
2 The term 'commercial institution' refers to the following: free trade agreements, common markets, economic unions and monetary unions.
} 
region have promoted intra-regional trade. Secondly, it then analyses if trade has an impact on promoting peace within the region. One hypothesis is tested at each stage of this study:

Hypothesis 1: commercial institutions in the MENA promote trade within the region;

Hypothesis 2: higher levels of bilateral trade promotes peace by deterring aggression (deterrence arises because trade increases economic interdependence which raises the opportunity costs of conflict, while at the same time increasing the rewards of cooperation). Therefore, increased trade and economic integration between MENA states will lead to increased political cooperation and greater potential for peace and stability at the regional level.

The study begins by summarizing the main assumptions of CIP and charts the development of this approach through a review of existing literature. Through a critique of CIP literature, we are able to identify the limitations of applying this theory to regional-level analyses. The study then proceeds to outline commercial institutions in the MENA and discusses how these have emerged out of the pursuit of national economic welfare and international peace. By critiquing the literature on commercial institutions, economic integration, and peace in the MENA this study then develops a bespoke methodology that introduces new variables into the analysis of the correlation between commercial institutions, economic integration and peace. This study then uses this methodology to analyze the relationship between commercial institutions, trade and peace between 20 states $^{3}$ in the MENA by dyadyear (a total of 380 dyads). The unit of analysis is the dyad-year over the period 1990-2014, totaling 9,500 dyad-years. SPSS is used to test for correlations between twelve variables that tell us about the nature of economic and political interactions in the region relevant to this study, by conducting bivariate correlate analysis using Pearson R to test for multi-variable correlation by dyad-year. A discussion of the findings is then presented, followed by final conclusions on the validity of the CIP for the MENA, and prospects for regional peace through economic integration. The conclusions drawn here are that commercial institutions in the MENA have only a very limited positive correlation with trade volume, and that economic integration has a limited positive correlation with peace.

\section{Commercial Institutional Peace}

As part of the liberal peace research agenda, we can identify a body of literature that investigates the relationship between trade-promoting government policies (commercial institutions) and peace/conflict (see: Polachek, 1980; Reuveny, 2001; Bearce and Omori, 2005; Goldsmith, 2013). As part of this

\footnotetext{
${ }^{3}$ These are: Algeria, Bahrain, Egypt, Iran, Iraq, Israel, Jordan, Kuwait, Lebanon, Libya, Morocco, Oman, Qatar, Saudi Arabia, Sudan, Syria, Tunisia, Turkey, UAE, and Yemen. Data for Palestine was insufficient to include it as a viable actor here. For example, the IMF's Direction of Trade Statistics was used to collect data, yet data for Palestine is not available.
} 
research agenda, scholars in International Relations (IR) and International Political Economy (IPE) have argued that states that interact with each other through commercial institutions will experience high levels of cooperation in their overall relationship (Oneal and Russett, 1999; Polachek et al., 1999; Bearce, 2003; Aydin, 2010; Goldsmith, 2013). The underlying thesis is relatively straightforward here: commercial institutions facilitate trade by removing both tariff and non-tariff barriers to economic exchange, this in turn increases trade volume. Over time, increased trade volume leads to greater levels of economic integration and interdependence between states (Benson and Niou, 2007; Kilchevsky, et al., 2007; Saez, 2008; Aydin, 2010). Economic interdependence, in particular, raises the costs of defection (in other words engaging in conflict/war), from any peaceful and cooperative trading relationship, while at the same time increasing the rewards of cooperation and the maintenance of peace (Kilchevsky et al., 2007; Gartzke et al., 2001). The end result is embedded inter-state cooperation, international stability and peace (Bearce and Omori, 2005; Oneal et al., 2003). This thesis is inspired by Norman Angell's Great Illusion (1913) - the illusion being that in an interdependence system, national interests can be achieved through conflict and war rather than peaceful interactions.

This area of investigation forms part of what Oneal et al. (2003) term "the causes of peace". This thesis is based on Kantian logic and the examination of the three legs of the Kantian tripod (republican constitutions, cosmopolitan law (free trade and economic interdependence), and international law) with Oneal et al. seeing the second as the most important (ibid, p. 372). They highlight the policy implications of the peace research agenda, and in particular the importance of understanding the relationship between each Kantian element when recommending 'that policymakers promote democracy and trade internationally and participate in international organizations as a means of promoting world peace' (ibid). CIP theory is undoubtedly rich with policy implications. The IR and IPE scholarship on commercial institutions has focused on whether or not trade promotes peace through reducing the prevalence of armed conflict. Here, peace is often understood as the absence of militarized interstate disputes (MIDs). The incidence of armed interstate conflict has been the measure of the success or failure of economic integration as a means to prevent conflict and promote peaceful cooperation. For example, Bearce (2003) has attempted to 'grasp' the CIP by analyzing how commercial institutions "help reduce the incidence of militarized inter-state conflict" (ibid, p. 347). Similarly, McDonald (2004, p. 547) explores how "higher levels of free trade [...] reduce military conflict between states", and Bearce and Omori (2005), Saez (2008), Aydin (2010) and Goldsmith (2013) have all studied different aspects of the trade and interstate-conflict relationship.

While this area of peace research has developed and is garnering increased attention, CIP is not yet a fully-formed approach with some studies undermining it. There are still questions about the assumptions made and critical studies exist that call the fundamental tenet (that trade and peace are directly and positively related) into question.

Polachek et al. (1999) find that foreign aid and contiguity increase the gains from trade, while tariffs have the opposite effect. Furthermore, their findings concretely demonstrate that the benefits 
from trade (and therefore, the promotion of peace and cooperation) are greater for small states when they trade with large states, than for small state-small state trade. Likewise, for large states greater benefits are experienced when trading with other large states than with small states (ibid, p. 418). In many ways a front-runner to more recent analyses, Polachek et al. argue that third party considerations have an impact on how trade affects conflict. They state that "[a]n actor with improved terms of trade [...] with a target [country] will decrease conflict with a third party [...] if the third party and target are friends" (ibid, p. 411). Furthermore, "[a]n actor with improved terms of trade with a target will increase conflict with a third party, if the third party and target are rivals" (ibid).

After examining 6,000 dyads and approximately 150,000 observations from 1885-1992, Oneal and Russett find that "democracy, economic interdependence, and involvement in international organizations reduce the incidence of [MIDs]" (ibid, p. 34). In terms of trade, this effect is very significant with important trade integration leading to a reduction in the likelihood of MIDs by over half. At the systemic level Oneal and Russett conclude that 'the international system is more peaceful when there are more democracies and when trade is greater' (ibid). Like most of the other literature on the Kantian peace or broader CIP research, Oneal and Russett's findings represent a universally applicable set of conclusions as the data they analyze covers all states.

In similar research, Bearce and Omori (2005) have built on earlier CIP research by investigating how "regional commercial institutions produce their observed pacific effect" (ibid, p. 659). They tested three causal arguments: firstly, that commercial institutions increase opportunity costs for war; second, that commercial institutions provide information on trading partners' military capabilities, thus increasing their ability to bargain for peace; and third, that commercial institutions regularly bring highlevel state leaders and decision-makers together which can help build trust (ibid). By using a statistical model that includes a range of variables and applying it to all region-specific politically relevant dyadyears from 1951-1985, Bearce and Omori conclude that only the third thesis tested is accurate (ibid, p. 668-669).

Of particular importance here is the way in which Bearce and Omori deal with the problem of which actors experience opportunity costs of war. If we consider states as unitary actors, then we can rather superficially argue that increased trade raises the opportunity cost of war through loss of trade. However, as Bearce and Omori (ibid, p. 662) highlight: "it is societal actors who conduct the bulk of international commerce, and thus, directly earn the profits of this exchange." As commercial institutions are created and maintained by state actors, we need to question how they benefit from economic interdependence, or how higher opportunity costs of war affect their decision making. Bearce (2003) offers one solution here by considering states as autonomous actors that are not impacted on by societal (or market) actors. In this way it is possible to explore whether state actors directly suffer economically through war. However, this approach is limited when studying commercial institutions if most of the benefits are received by market actors. Instead we can approach states as autonomous actors that need vibrant markets in order to raise revenue through tax, thus reinforcing the interest that states have in 
promoting economic growth and raising their opportunity costs of war (Bearce and Omori, 2005, p. 663). Another solution is proposed in this study and draws on work done by Polachek (1992), and Polachek and McDonald (1992), and highlighted by Barbieri (1996), in which "[1]eaders are deterred from initiating conflict against important trading partners for fear of losing welfare gains associated with trade" (ibid, p. 31).

In a related study Aydin (2008) examines the relationship between trade and its "broader political implications on state behavior" (ibid, p. 1098) and not just its impact in MIDs. In particular Aydin looks beyond dyads consisting of trading partners and considers trade's impact on states' decisions to assist their trading partners militarily (when they are in conflict with third parties). Using a similar methodology to that employed in her 2010 work, Aydin (ibid) finds that "[w]hen third parties have important trade interests in a conflict participant, they join with their partners to protect their economic stakes". This approach offers us an interesting way of examining trade's broader effects beyond dyadic analysis. In particular, Aydin (ibid, p. 1099) argues that "[t]hird party states that are interdependent with conflict participants fear disruption of trade" and will, therefore, have an interest in conflicts that they are not (at least initially) involved in militarily. This model of 'conflict expansion' demonstrates that economic interdependence and international peace/conflict are related and are more complex than dyadic analyses have proven. This conclusion has implications for understanding the pacific benefits of trade at the regional level and suggests a complex regional system of trading relationships and subsequent economic interdependence will magnify the potential for regional involvement in promoting peace and/or fighting wars.

In regards to trade, Oneal et al. (2003) find that there is a pacifying effect, with economic interdependence having a significant impact on reducing the risk of fatal disputes and wars (ibid, $p$. 387-388). Interestingly, however, the nature of governing regimes is also found to have robust impact on promoting peace, with democracies that trade significantly with each other being least likely to engage in militarized conflict. This finding has implications for an assessment of the impact of commercial institutions in the MENA as most states considered here are authoritarian. Central to McDonald's (2004) approach is the observation that increasing trade tends to increase overall national economic prosperity but at the same time also alters the domestic distribution of income. Some domestic groups (actors in import-competing sectors, for example), therefore, are likely to resist greater economic integration and will not "lobby the state for a pacific foreign policy that promotes expanding transnational economic ties" (ibid). Free trade removes the foundations of domestic privilege for those groups who are likely to resist economic integration in the form of imports, and thus reduces the capabilities of these groups to "reduce the capacity of free-trading interests to limit aggression in foreign policy" (ibid, p. 549).

Not all research has been as optimistic about the value of trade-promoting policies as a means to peace. Kim and Rousseau (2005) find that "states that share preferential trading agreement(s) [...] are more likely to be interdependent with each other; but, economic interdependence is higher between 
states across regions rather than within regions" (ibid, p. 540). Nevertheless, their key finding is that economic interdependence does not have a pacifying effect. Likewise, Barbieri's work has furthered the CIP research agenda by re-examining the relationship between economic interdependence and peace/conflict by considering the impact of varying levels of interdependence on state behavior. She takes a historical approach and analyses the impact of economic interdependence on interstate relations during the $19^{\text {th }}$ and $20^{\text {th }}$ centuries, and finds that " $[\mathrm{r}$ ]ather than inhibiting conflict, extensive economic interdependence increases the likelihood that dyads will engage in militarized interstate disputes" (ibid, p. 29). Furthermore, "[e]xtreme interdependence, whether symmetrical or asymmetrical, has the greatest potential for increasing the likelihood of conflict" (ibid). These conclusions run counter to the dominant hypothesis that trade promotes peace and Barbieri's work encouraged further investigations to test her model. Key to this approach is consideration of both the benefits and costs of trade. The latter has generally been ignored by liberal scholars who focus on the positive effects of trade as a means to understand increased opportunity costs and increased rewards from trade. Barbieri (ibid, p. 31) finds that if costs are greater than benefits then trade may lead to conflict rather than peace, especially in an asymmetric trading relationship.

According to the results of the full interdependence model employed in her study, Barbieri concludes that "the extension of trade linkages will inevitably lead to an increased probability that dyads engage in militarized disputes" (ibid, p. 40). Furthermore, "when interdependence is at its maximum, dyads are 25 times as likely to engage in a MID than when interdependence is at its minimum" (ibid). These findings are contrary to much of the scholarship that supports the liberal peace thesis. A reason for this disparity may be the differences in time periods analyzed (with Barbieri focusing on the preWorld War Two period, and other studies considering longer periods with data up to the 2000s). Another might be the exclusion of some variables such as the impact of the perceptions of state leaders; the impact of trust, norms and formal mechanisms for state leaders to communicate; cultural similarity; and historical relations.

Lawrence Saez (2008) argues "that under certain specific conditions, trade interdependence is unlikely to occur and therefore the expected palliative effect of trade on militarized inter-state conflict cannot take place" (ibid, p. 698). While his study still focuses on the relationship between trade and inter-state war (which limits our understanding of how trade can promote political cooperation in other areas of international relations), his assessment of the limits of trade occurrence is highly valuable. Saez's conclusions have direct implications for the effect of trade on various aspects of political cooperation (not just conflict reduction) and can be used to demonstrate when commercial institutions do not lead to greater trade and economic integration. His central thesis draws on neo-realist literature and states that "trade is inherently conflictual" (ibid) and especially where the following conditions apply: "where there is intermittent military friction [and] asymmetry among players" and where there this a regional hegemon, which "is likely to be hostile to the interests of its neighbors" (ibid). A second argument posited by Saez is that states that have a history of military conflict with each other will not 
increase bilateral trade with each other, instead finding alternative partners to economically integrate with (ibid, p. 699). Yet as Page (2000, p. 62) highlights, "it is precisely former enemies which may want to institutionalize the end of conflict". Understanding when enemies become former enemies is, therefore, important. To test this position further it is necessary to examine the impact of commercial institutions on creating or diverting trade between member states at the regional level.

There are also implications for research that focuses on specific regions here. Saez's main findings are that 'some regional economies are not structurally disposed to undertake trade' (ibid, p. 713); and that trade does not lead to peace when "the conflict-reducing options that are contingent upon the nature of economic interdependence are not present" (ibid). One limitation with these conclusions, however, is that they are used interchangeably to support the central thesis that trade does not promote peace, when perhaps there are two separate questions being addressed that relate to whether trade takes place, and if it does what is the impact on conflict reduction. The relevance of Saez's work for the present study is how the first question is addressed and not the broader question of whether or not trade (when it does occur and when economic integration leads to interdependence) leads to peace. This study reflects on Saez's conclusions about the former question.

Reflecting on studies that have both supported and contradicted CIP theory is necessary to promote a more heterodox approach to the analysis of commercial institutions, economic integration and peace. An intriguing finding made by Reuveny (2001), for example, is that there are differences in the relationship between trade and conflict/cooperation when considering relations between Eastern and Western states on the one hand, and between states within the West on the other. Specifically, Reuveny finds that "the East-West trade and conflict nexus is generally more significant than the West-West nexus and is potentially more sensitive to conflict" (ibid, p. 132). The implications of this finding are that trade does not have one universally applicable effect on other areas of international relations (and vice versa) and that different regions can experience the impact of trade in various ways. This raises questions about the impact of trade within specific regions (and not just between states across regions) outside of the West. In the context of this current study: the MENA. The overarching finding made by Reuveny is that "trade and conflict theories may miss important elements, pointing out the need for richer, more microfounded theoretical models" (ibid).

Likewise, Goldsmith (2013) concludes that trade can have both a positive and negative effect on international relations at different times. In some cases, trade does inhibit conflict between states, but it can also facilitate it under certain conditions (ibid, p. 575). Specifically, he finds that: "trade interdependence inhibits the onset of militarized disputes, trade volume increases the risk of the onset of militarized disputes, there is no relationship between trade interdependence and conflict escalation, and trade volume inhibits the escalation of militarized disputes to deadly interstate violence" (ibid). The second conclusion is perhaps the most interesting, and unexpected if one adopts widely held assumptions about the liberal peace. This suggests an avenue for research concerning the effects of commercial institutions, trade volume and interdependence at the regional level in the MENA. 
Goldsmith's study centers on the hypothesis "that trade interdependence, representing the opportunity costs of conflict, is likely to deter conflict onset, but that high volumes of trade, by increasing potential sources of tension, will make onset more likely [but] these roles reverse once a conflict has begun and states consider escalation to war" (ibid, p. 556) (italics in original).

Bearce (2003) has noted that while much work has been done to advance the CIP agenda, and "this research program now provides stronger empirical evidence that commercial institutions produce positive security externalities in the developing world, it still fails to delineate clearly how such institutions matter" (ibid, p. 348) (italics in original). Using a similar approach to Oneal et al. (2003), Bearce (2003) tests the argument that commercial institutions influence international relations in several ways: first, by "increasing the opportunity costs of war for the state"; second, providing state leaders with information "about other states' military capabilities and [...] intentions"; and third, building trust between state leaders by bringing them together on a regular basis. One limitation with this final argument, however, is that the role of security apparatus is quite prominent in Bearce's analysis. In particular, if the commercial institution being studied is embodied in an international organization (and not just an agreement) that deals with security in a traditional sense (considering war, sovereignty, military security and survival) then the argument that commercial institutions offer state leaders the opportunity to meet to discuss security issues stands up. But if the commercial institution exclusively relates to liberalizing trade between member states, and is just one agreement (among potentially many) formulated and maintained by an organizational forum that deals with economic and social issues (like the Arab League's Economic and Social Council that oversees GAFTA) then the argument is harder to support.

Benson and Niou note "that asymmetries in economically integrated dyads are likely to create incentives for the less dependent actor to exploit its bargaining leverage to manipulate the more dependent actor" (ibid, p. 39). This approach certainly has some value and has helped to further our understanding of the trade-peace relationship, however, it risks placing too much emphasis on state actors without considering society/market actors and their role in initiating and maintaining trade. This poses problems because states are not the primary actors engaged in the production and exchange of goods and services. As Barbieri (1996, p. 31) notes, at least for liberal scholars, "trade patterns emerge naturally as a result of given heterogeneous factor endowments". While Benson and Niou's claim that the "[f]ailure to endogenize decision-makers' choice to trade is a critical short-coming of existing trade studies" (ibid, p. 40) is valid, this critique ignores the possibility that state leaders do not in fact have the power to decide whether or not to trade. Analyzing market forces can prove far more fruitful in understanding why and how trade takes place as this approach allows us to examine the actual actors involved in production, exchange and consumption (which includes state actors only to some extent). Indeed, if the argument that states decide whether to trade or not is accurate then the establishment of commercial institutions would automatically result in increased trade. This is, however, not guaranteed and empirical studies have shown that the implementation of an FTA does not always have any impact 
on trade patterns. Studies that fail to differentiate between states and markets often prove ineffective (see: Strange, 1994).

We can consider the domestic-stability effects of economic growth in the MENA as being highly important to perhaps the most central policy goal of governing regimes in the region: regime survival (Ismael et al. 2015). As most states in the region express authoritarian as opposed to democratic tendencies, tenure in office is not lightly considered, and the notion of political change as a normal process is often not respected. We can, therefore, consider economic gains by market actors as highly relevant to the state actors engaging in regional commercial institutions. If society gains from increased trade, so too do states through increased stability, likewise if society experiences economic hardship, for example from war, then states also suffer through increased instability. Furthermore, the distinction between state and 'societal' actors that Bearce and Omori highlight only applies in an ideal-type capitalist economy. The relationship between MENA governments and big business, for example, is highly complex and often ruling elites and economic elites are synonymous with each other. These considerations inform the methodology applied in this study as discussed below.

\section{Commercial Institutions in the MENA}

The history of commercial institutions in the MENA is significant in terms of the number of initiatives and governmental commitment to creating such institutions. However, the impact of these institutions has been less impressive (Ekanayake and Ledgerwood 2009). The region has a number of bilateral and multilateral FTAs, and a common market (the GCC) that are exclusive to the region - and when considering the international and global levels, MENA states are involved in several dozen commercial institutions. Governments in the region have created this plethora of MENA-specific commercial institutions in order to promote domestic economic welfare at home (Konan 2003), and broader integration and cooperation at the regional level. The most encompassing agreement is the Greater Arab Free Trade Area (GAFTA) which was signed at the League of Arab States General Meeting on February 191997 in Amman, Jordan (El-Anis, 2011, pp. 90-92). According to Jamel Zarouk (2003) GAFTA was created, at least in part, in order to promote intra-Arab trade in light of broader international agreements and processes, for example, the signing by a number of MENA states of Association Agreements with the EU, and the Uruguay Round of WTO negotiations. GAFTA was an attempt to revive the Arab League's moribund 1981 Agreement for Facilitation and Promotion of Trade, and has resulted in the full liberalisation of trade in goods (services are not included in the agreement) between member states. The following states are members of GAFTA: Algeria, Bahrain, Egypt, Iraq, Jordan, Kuwait, Lebanon, Libya, Morocco, Oman, Palestine, Qatar, Saudi Arabia, Sudan, Syria, Tunisia, the UAE, Yemen.

The 1980s saw the creation of the Gulf Cooperation Council (GCC) and the Arab Maghreb Union (AMU). The former, consisting of Bahrain, Kuwait, Oman, Qatar, Saudi Arabia and the UAE is a common market (Low and Salazar 2011) and since 2008 the group has been pursuing the 
establishment of a single market. Internal trade and movement of people and capital is fully liberalised. The AMU was established by Algeria, Libya, Mauritania, Morocco and Tunisia in 1989 and sought to create a common market (Darrat and Pennathur 2002). However, most policies created in this forum have not been implemented, or have been under-implemented. GAFTA has had a somewhat uneven development with some members implementing the agreement at different rates (Al-Atrash and Yousef 2000). This in part encouraged Egypt, Jordan, Morocco and Tunisia implemented the Agadir Agreement (also known as the Mediterranean Arab Free Trade Agreement (MAFTA)) on 25 February 2005 (Peridy 2005). This FTA seeks to liberalise all trade between the member states. In addition to these agreements there are a number of bilateral trade agreements (including some FTAs) between Arab League member states and Turkey, Israel and Iran.

CIP theory has developed since the 1990s yet we can still identify limitations in terms of the assumptions made and the absence of the MENA from the research agenda. Kilchevsky et al. (2007, p. 647), for example, have highlighted the need to "move from the general insight offered by past studies to more region-specific models and analyses at lower levels of aggregation." Given the limited levels of intra-regional trade in the MENA and the fact that the region has "for the most part, avoided the global trend of regionalism" (ibid, p. 648) it is perhaps more useful to analyze trade patterns and policies across the region. This study thus analyses a large-scale set of relations that demonstrate a greater level of embedded economic, political and institutional engagement in the MENA as this can provide further insights into the relationship between economic interactions, political cooperation, peace and security at the regional level.

In order to develop our understanding of the potential for peace in the region we need to bring economic considerations into the discussion. Abboud and Minow (2002, p. 14) put forward the case for an "economics first" approach arguing that "economic interaction often leads to political adhesion" and noting that "examples can be found in Western Europe and Eastern Europe and increasingly in Asia. Politics follows commerce because commerce provides mutual benefits across the broad expanse of the population, regardless of race, color, religion, or ideology" (ibid). The experiences of the world of business (where risks are taken far more readily than in the world of politics) certainly lend support to this notion. However, as Abboud and Minow admit, "[g]etting agreement on the stabilizing potential of economic development is easy. Translating that agreement into actual progress on the ground is tough" (ibid). Investigating the ways in which state policies in the MENA exhibit agreement that "trade is good" is an important step, but analyzing how commercial institutions are established only takes us so far in our understanding of the political economy of trade and peace in the MENA. Exploring how agreements translate into actual progress on the ground in terms of peace is an interesting avenue for research.

It is also important to address the lack of analysis of the correlation between economic and political processes at the regional level of analysis. Aydin (2010, p. 523) notes the limitations of focusing solely on the direct deterrent effects of trade in any given bilateral relationship. This rather 
narrow research interest, it is argued, has been the dominant focus of much of the literature on economic interdependence and international conflict, which has tended to omit bilateral trade's indirect effect on third-party states. By going beyond the dyad-level analysis, Aydin concludes that "extended deterrence success is most likely in cases where the defender and target are economically integrated through regional trade institutions as well as conducting heavy trade" (ibid). The conclusion that regional trade institutions (in this study referred to as a specific form of commercial institution) are important to the promotion of peace and stability is particularly noteworthy. Indeed, Aydin shows that an assessment of the impact of trade on political behavior and relations between multiple states requires an appreciation of the role of regional commercial institutions and a large number of overlapping dyadic analyses. Furthermore, an analysis of this kind can offer insights into the impact that trade has on states directly engaged in trade with each other as well as the deterrent effect of economic and institutional integration on third-party states (states that are not directly engaged in said integration) (ibid, p. 524), in other words an entire region.

As highlighted above, research on the relationship between economic integration and peace has developed since the mid-1990s, yet the MENA has largely been ignored. Perhaps this is a result of the rather inaccurate perception of what Doug Henwood (1993) refers to as "the missing Middle East" in processes of global economic integration. Studies that have tackled economic integration and peace in the MENA have been few in number and somewhat limited in scope. Bessma Momani (2007) has analyzed economic interdependence and peace in the context of the Bush Doctrine, highlighting the Bush Administration's plan of "expanding trade and economic relations with friendly Middle East states [to] advance America's strategic interests" (ibid, p. 1682). Momani examined the so-called Middle East Free Trade Area (MEFTA) and the US interest behind it, as well as the structural barriers to intraregional trade in the MENA. Momani argues that there are four key structural problems: first, low comparative advantage; second, the small size of MENA economies; third, income disparity between MENA states; and fourth, high tariff and non-tariff barriers to trade. While this study contributes to our understanding of these structural limitations, and US policy interests, it does little to advance our knowledge of the actual potential for increased economic integration to achieve the overall objective of promoting peace and stability in the region. Ultimately, Momani concludes that " $[\mathrm{t}] \mathrm{he}$ current structural impediments to intra-regional economic cooperation [...] will inhibit the prospects for of an integrated Middle East economic system" (ibid, p. 1698). This is undoubtedly a significant conclusion, but leaves unanswered questions related to the pacific benefits of trade when it does take place.

A final problem to overcome is that studies of trade policy in the MENA often focus on governmental strategies and less so on the impact of economic interactions. For example, Mosad Zineldin (2002) has explored different strategies "needed to achieve the Arab shared objective of cooperation and peaceful coexistence" (ibid, p. 35) by considering both micro- and macro-economic factors that promote and hinder integration. It must be noted here that non-Arab MENA states are excluded from his analysis - which is certainly a limitation given the roles played by Iran and Turkey, 
in particular, in the region's economy. Zineldin sees emergent regional trading blocs resulting from the pressure of increased competition (both economic and political) stemming from globalization. Trade for Arab states, Zineldin argues, is as much about regional defense against the global economy as it is about synergy between them. He argues that a strategy is needed to promote economic integration between Arab states in order to better ensure their survival and development in the $21^{\text {st }}$ century (ibid, $\mathrm{p}$. 37). However, in a similar analysis to Momani's, Zineldin does not consider the effects of economic integration on political cooperation and MIDs. Rather, an effect is assumed - to positively reinforce cooperation and coordination between trading partners in the Arab world.

\section{Methodology}

Analyzing the relationship between commercial institutions and peace/conflict is complex and various methodological approaches have been used to this end. The multiplicity of methodologies exists in part because no single approach has proven sufficient to explain this contested area of investigation. As with debates surrounding the underlying theoretical assumptions about commercial institutions and peace/conflict, there are competing arguments about which variables need to be analyzed in order to understand if there is a CIP. At the same time, no 'ready-made' methodology to analyze the MENA experience is available. Kilchevsky et al. (2007) offer one of the more coherent (of a small number of) studies that seek to investigate how "economic interdependence can be converted from a theoretical construct to a concrete reality" (ibid, p. 648) in the MENA. By using three least square regression analysis with conflict as the dependent variable and trade patterns as the independent variable they find that the four countries tested are more peaceful when they are more economically integrated (ibid). However, limiting their study to Egypt, Israel, Jordan and Turkey may distort the conclusions as the dyadic relationships tested are Egypt-Israel, Jordan-Israel, and Turkey-Israel, each of which is a relationship influenced by other independent variables such as treaties of peace which also provide for joint economic ventures (in the cases of Egypt-Israel and Jordan-Israel) or close defense ties (TurkeyIsrael). Egypt-Jordan, Egypt-Turkey and Jordan-Turkey are not tested as dyads and little can be learned about whether or not they are more or less peaceful towards each other given greater or lesser levels of economic integration by an analysis that ultimately puts Israel as the central dyadic partner. Relationships between Egypt and Jordan, for example, are influenced by rather different interests, identities, histories, and processes to Egyptian-Israeli relations, some but not all of which are used as control variables by Kilchevsky et al. (who use: conflict, salience, symmetry, interdependence, relative power, difference in democratization, contiguity and IGO membership as control variables).

While Kilchevsky et al. offer a useful methodological starting point, understanding the nature of economic integration and its impacts on political interactions in the MENA requires a more comprehensive analysis that takes into account a larger range of dyadic relationships, and that considers a greater number of variables that inform trade policies and patterns. Oneal et al. (1996) have evaluated 
the "effects of regime type and interdependence on the likelihood that a pair of states will become involved in a militarized interstate dispute" (ibid, p. 11). They do this by controlling for growth rates in per capita income, alliances, geographic contiguity, and relative power and use logistic regression analyses for a large number of dyads from 1950-85. At the time this work was published (1996) it was evident that, as Oneal et al. state, "political scientists have shown less interest in the consequences of free trade and economic interdependence" (ibid) than in the relationship between democracy and international conflict. While this is no longer quite the case, given the research that has been carried out since the mid-1990s, Oneal et al.'s work still resonates with scholars trying to fully understand how economic interdependence promotes peace. In all, Oneal et al. analyze militarized inter-state disputes (MIDs) and limit their study to dyads that are politically relevant and contiguous (ibid, p. 14). This offers some ground for the methodology employed in this study to develop from in a similar way to other studies that followed Oneal et al.'s work (see: Benson and Niou 2007).

One limitation here, however, is that no rigorous method/justification for defining which states are politically relevant. Furthermore, in today's era of globalization the rapid advancement of travel and communication technologies, as well as the increasingly global nature of research and design, production, marketing and sales processes, trade is no longer focused on neighbors (see: Ohmae 1994). In short, we need to take into account trade between states that are not contiguous while still considering the impact of distance and borders. This position raises some important questions for the deterrence and peace-promoting effects of regional agreements like the GAFTA when considering that, as demonstrated by Elkhafif at el. (2012), Rouis (2012), Romagnoli and Mengoni (2009), Abedini and Péridy (2008) among others, the evidence suggests that this agreement has had only a modest impact on increasing trade within the region, and much of this has been within sub-regions of the MENA.

It is clear that a methodology that considers a large number of variables is needed. Polachek et al. (1999) have demonstrated this by building on some of the earlier peace research literature by introducing new variables into older models. They argue that foreign aid, tariffs, contiguity and relative country-size also need to be analyzed as independent variables (ibid, p. 405). By integrating these additional factors into their methodology they are able to demonstrate how trade affects conflict/peace in a more robust manner than earlier studies that only considered total levels of bilateral trade and levels of interdependence by dyad-year. Yet, while Polachek et al.'s approach has developed our understanding of the impacts of trade on conflict/peace, there are still limitations in terms of the independent variables measured. Their model leaves no room for an assessment of the impact of a range of variables that according to other works, are demonstrably important: including, cultural affinity and military capabilities. A limitation with many of the models employed in the liberal peace literature, especially investigations of trade and commercial institutions, often are limited by the relatively small number of variables considered. Goldsmith (2013) takes a rather unique direction in trade and peace research by "integrating expectations from schools of thought often portrayed as incompatible [to analyze] two aspects of trade - volume and interdependence - and model conflict as a two-stage process 
involving onset and escalation" (ibid, p. 555). Yet, by considering trade as the key variable, and not exploring the effects of other variables Goldsmith offers an explanation of the impact of trade that does not account for the simultaneous effects of forms of governance, institutional membership, contiguity/proximity, and history, for example. But he does highlight that there is still much to be researched and he offers some insights into how we can deepen our understanding of the ways in which patterns of trade can affect international relations.

\section{Research Design}

This study examines the relationship between commercial institutions, trade and peace between 20 states in the MENA and a total of 380 dyads. The unit of analysis is the dyad-year over the period 19902014, totaling 9,500 dyad-years. Data was collected on twelve variables that provide us with evidence of the nature of economic and political interactions in the region (the variables and sources of data are discussed below). This data was then processed using SPSS to ascertain the level of correlation between the variables by conducting bivariate correlate analysis using Pearson $\mathrm{R}$ to test for multi-variable correlation by dyad-year.

This study was carried out in two stages, each relating to one of the key hypotheses being tested. Each phase has one independent variable, one dependent variable, and a number of control variables. The first stage explored the relationship between commercial institutions (the stage one independent variable) and trade volume (stage one dependent variable). The second stage explored the relationship between trade (the stage two independent variable) and peace (stage two dependent variable).

\section{Stage one}

The independent variable - Commercial Institutional Membership. This project classifies commercial institutions into five categories depending on degree of intensity. A bespoke dataset has been created for commercial institutional membership. The data was collated from World Trade Organization country reports ${ }^{4}$ and corroborated by respective national ministries. This dataset contains scores for each dyad-year on a scale of $0-5$ by coding for the highest level of engagement using the following approach: 0 where there is no commercial institutional membership; 1 where a weak FTA (bilateral of multilateral) covers goods only with significant exemptions; 2 where a limited FTA (bilateral or multilateral) exists that covers goods only with limited exemptions; 3 where a comprehensive FTA (bilateral or multilateral) exists that covers goods and services with only limited exemptions; 4 for a common market; and 5 for a full economic union.

The Dependent Variable - Trade Volume (1990-2014). The creation of a dataset on bilateral trade between states in the MENA was accomplished using the International Monetary Fund's Direction of

\footnotetext{
${ }^{4}$ The WTO database on existing members and organizations can be accessed here: https://www.wto.org/english/thewto e/whatis e/tif e/org6 e.htm
} 
Trade Statistics database. ${ }^{5}$ Data was collated in current US\$ for each dyad-year for the period 19902014.

A further six control variables are used here as follows:

Trade compatibility/trade congruence. Saez (2008) employs a useful concept of trade congruence/incongruence as being central to understanding the structural promotion/inhibition of bilateral trade. Here the structure of each states' export base (their leading export goods and services) and import base (their leading goods and services imports) are considered. Where one dyadic state's export base is equivalent to its partner's import base, this state can be classed as unilaterally congruent (ibid, p. 708). If both states' exports bases are equivalent to each other's import bases the dyad is classed as bilaterally congruent (ibid). If neither sate's export base is equivalent to the other's import base, then the dyad is incongruent (ibid). This study uses the concept of trade congruence/incongruence to understand the potential for trade. The IMF's Direction of Trade Statistics database was used to create a bespoke dataset on each state's leading exports and imports for 1990-2014. A score was then created reflecting the congruence/incongruence for each dyad-year.

Contiguity and proximity/distance. As highlighted above, even in a globalizing world, distance places demands and constraints on the transportation of goods, resources and people. If greater distance reduces the capability to fight, it can also reduce the potential for trade. Trading over greater distances may be limited in some respects due to the time and cost involved (for example, trade in fresh agricultural produce can be constrained by the time required to travel greater distances. Increased transport costs can reduce profits, thus lowering the exporter's incentives to trade). At the same time the number of regulated borders and the associated customs procedures can also have a restrictive effect on trade. Dyads are coded as 3 if the dyad states share a land or littoral border; 2 if they are separated by one state; 1 if they are separated by two states; and 0 if they are separated by three or more states.

Cultural Affinity. Actor behavior can be influenced by awareness of perceived and actual cultural affinity. This study defines cultural affinity as the extent of shared language and religious characteristics, and posits that where cultural similarities are intense (for example, where two communities share the exact same language and religion) there will likely be an impact on bilateral trade. Culture can influence the types of goods and services that are required, for example, food and clothing products that meet specific religious standards; or services provided in a common language, such as Arabic. A score of 0 is assigned where $0-9 \%$ of the population of each state share the same cultural element; 1 is assigned where $10-39 \%$ of the population share the same cultural element; 2 is assigned where $40-79 \%$ of the population share the same cultural element; and 3 is assigned where $80+\%$ of each population share the same cultural element.

Population size. The size of a population directly relates to market size (when combined with GDP and GDP per capita). Market size determines the potential for trade, with an advanced, large market of

\footnotetext{
${ }^{5}$ The IMF Direction of Trade Statistics database can be accessed here: https://www.imf.org/en/data\#data
} 
affluent citizens having the ability to purchase goods and services (leading to high demand for imports), and large productive capacity (the ability to produce/provide goods and services for export). Less advanced, small markets with poor citizens, on the other hand, will have limited import needs due to low purchasing power and low demand, and less productive capacity and thus low export potential. The World Bank's Databank ${ }^{6}$ has been used to create a dataset on population sizes for each state for the studied period.

GDP Size. The size of a state's economy, as measured by GDP (purchasing power parity (PPP) method) acts in much the same way as population size, in shaping demand for imports, and capacity for exports. The World Bank's Databank has been used to create a dataset on GDP PPP for each state for the studied period.

GDP per capita. The total size of a state's economy is determined, not only by overall GDP and population, but also by the affluence of the population and, therefore, the purchasing power of individual consumers. A relatively large GDP but small affluent population may limit potential for imports and exports. Likewise, a large, yet poor population will also limit potential for imports and exports. Assessing the purchasing power of individual consumers is, therefore, necessary. The World Bank's Databank has been used to create a dataset on GDP per capita (PPP) for each state for the studied period.

\section{Stage two}

The independent variable - Trade Volume (1990-2014). The same dataset on trade volume for each MENA dyad-year used in stage one is used here.

The Dependent Variable - Peace. Pease is a difficult concept to quantify, measure and analyze. Building on work done by other scholars, this study considers peace to be the absence of MIDs. As such, where an MID exists we can conclude peace is absent. This study follows Oneal and Russett (1999) and Aydin (2010), and uses data on militarized actions from the Correlates of War (CoW) MIDs v.2.1 Dataset. ${ }^{7}$ Where a MID has taken place in a dyad-year 1 is used, while 0 is used if no MID occurred.

A further five control variables are used at this stage as follows:

Contiguity and proximity/distance. As highlighted above, under normal conditions (i.e. where one or both dyad states are not global hegemons or great powers) the farther two states are from each other the less they have to fight about. Therefore, contiguity may increase the chances of conflict, while dyadic peace increases along with distance. The same dataset used in stage one is used here.

\footnotetext{
${ }^{6}$ The World Bank Data Bank can be accessed here: http://databank.worldbank.org/data/home.aspx

${ }^{7}$ The CoW MID dataset be accessed here: http://www.correlatesofwar.org/data-sets/MIDs
} 
Regime Type (form of governance). Data on political regime types was collated using the Centre for Systemic Peace's Polity IV project, ${ }^{8}$ where each state being studied here is awarded a score on a scale of +10 (absolute democracy) to -10 (absolute autocracy) for each year from 1990 to 2014. This methodology allows us to control for the more pacific behavior of democratic states and the more aggressive behavior of autocratic states. The assumption held here being that a dyad constituted by two democratic states (with higher Polity IV scores) will be more peaceful than dyads constituted by either one democratic and one autocratic state, or two autocratic states.

Military capabilities (composite indicator of national capabilities (CINC)). It is important to consider the balance of power/balance of threat. Where one dyadic state is militarily superior, the weaker state is more likely to be deterred by the imbalance of power that favors its partner. The opposite may be true for the more dominant state which will not be deterred in the same way. A dataset of national military capabilities has been created using the Correlates of War's National Material Capabilities v. $4.0^{9}$ - the composite index of national capabilities (CINC) scores for each state for each year being studied have been used. This data considers: iron and steel production; military expenditures; military personnel; primary energy consumption; total population; and urban population.

Alliance. State behavior can be constrained/influenced by alliances and so it is important to assess the nature of any formal alliance agreements between the states being studied here. The CoW's Formal Alliance v.4.1 dataset ${ }^{10}$ is used here to collect data on four types of alliance: defense, neutrality, nonaggression, and entente pacts, covering the 1990-2014 period of study. This dataset has been used to score all individual dyads $0-4$ according to the number of formal alliance elements ( 0 where no formal alliance exists; 1 where only one element (e.g. a defense pact) exists; 2 where two elements exist; 3 where three elements exist; and 4 where all four formal alliance elements exist).

Cultural affinity. As explained above.

\section{Findings and Discussion}

The results of the correlation test are clear and demonstrate a number of relationships between different variables, however, there are variations in the significance factor of these correlations. The most important finding is that there is a direct and positive correlation between the level of commercial institutional membership and trade volume at the dyad level in the MENA for 1990-2014. According to the analysis of the data collected, where a commercial institutional relationship exists total trade between member-states will be higher than if no commercial institution exists. At the same time,

\footnotetext{
${ }^{8}$ The Polity 4 country reports can be accessed by the Center for Systemic Peace website: http://www.systemicpeace.org/p4creports.html

${ }^{9}$ The CoW National Material Capabilities dataset can be accessed here: http://www.correlatesofwar.org/datasets/national-material-capabilities

${ }^{10}$ The CoW Formal Alliance dataset can be accessed here: http://www.correlatesofwar.org/data-sets/formalalliances
} 
however, the correlation value of .126 (significant at the 0.01 level) suggests that the correlation between commercial institutional membership and trade volume, while positive, is somewhat limited. Trade volume, for example, has a stronger direct positive correlation with a number of other variables, including: contiguity (.155 significant at the 0.01 level), population size (.140 significant at the 0.01 level), and GDP (.338 significant at the 0.01 level). In terms of positive correlation with trade volume, the test finds that commercial institutions only rank forth out of nine variables. The rank order from the most significant positive correlation to most significant negative correlation is as follows: 1) GDP; 2) military capabilities; 3) contiguity; 4) population size; 5) commercial institutional membership; 6) GDP per capita; 7) MIDs (negative); 8) cultural affinity (negative); and 9) alliances (negative). Regime type and trade congruence do not have a recordable correlation to trade volume. 
Table 1. Results of the Pearson Correlation Test

\begin{tabular}{|c|c|c|c|c|c|c|c|c|c|c|c|c|c|}
\hline & & $\begin{array}{c}\text { Trade } \\
\text { Vol. }\end{array}$ & MIDs & $\begin{array}{c}\text { Comm. } \\
\text { Inst }\end{array}$ & $\begin{array}{l}\text { Trade } \\
\text { Congr. }\end{array}$ & Contiguity & $\begin{array}{l}\text { Cultural } \\
\text { Affinity }\end{array}$ & \begin{tabular}{|c|} 
Population \\
Size
\end{tabular} & GDP & $\begin{array}{c}\text { GDP Per } \\
\text { Capita }\end{array}$ & $\begin{array}{c}\text { Regime } \\
\text { Type }\end{array}$ & Alliances & $\begin{array}{c}\text { Military } \\
\text { Capabilities }\end{array}$ \\
\hline \multirow{3}{*}{$\begin{array}{l}\text { Trade } \\
\text { Vol. }\end{array}$} & $\begin{array}{c}\text { Pearson } \\
\text { Correlation }\end{array}$ & 1 & $-.056^{* *}$ & $.126^{* *}$ & -.008 & $.155 * *$ & $-.082 * *$ & $.140 * *$ & $.338 * *$ & $.094 * *$ & .000 & $-.098 * *$ & $.181 * *$ \\
\hline & Sig. (2-tailed) & & .000 & .000 & .408 & .000 & 000 & .000 & .000 & .000 & .965 & .000 & .000 \\
\hline & $\mathrm{N}$ & 9479 & 9477 & 9479 & 9476 & 9479 & 9479 & 9106 & 8920 & 8992 & 8092 & 9342 & 6821 \\
\hline \multirow{3}{*}{ MIDs } & $\begin{array}{c}\text { Pearson } \\
\text { Correlation }\end{array}$ & $-.056 * *$ & 1 & $-.203 * *$ & $-.081 * *$ & $.127 * *$ & $-.302 * *$ & $-.071 * *$ & $.050 * *$ & $.087 * *$ & $.359 * *$ & $-.362 * *$ & $.052 * *$ \\
\hline & Sig. (2-tailed) & .000 & & .000 & .000 & .000 & .000 & .000 & .000 & .000 & .000 & .000 & .000 \\
\hline & $\mathrm{N}$ & 9477 & 9498 & 9498 & 9495 & 9498 & 9498 & 9118 & 8932 & 9004 & 8092 & 9358 & 6821 \\
\hline
\end{tabular}

**. Correlation is significant at the 0.01 level (2-tailed). 
The relationship between alliances and trade volume is surprising in so far as it has a negative correlation. It is possible that states with a more developed alliance are aware of the economic interdependence between them resulting from high trade volume, and thus would solidify their peaceful relationship in the form of an alliance. This does not seem to have happened in the MENA. However, for most of the MENA states considered in this study, their alliance status long-predates any relevant economic interactions (especially for Arab League member states). It is not possible to conclude here whether or not alliance status has an effect on trade volume, and this needs further investigation - as mentioned above, MENA governments can be heavily involved in market interactions as the lines between state and big business are often blurred. The fact that trade congruence does not have a recordable correlation with trade volume is surprising. It is widely accepted that the more well-suited two markets are, the more likely trade between them will flourish. The experience in the MENA does not correspond to this prediction, however, and the reasons why are unclear. The ranking of cultural affinity is also noteworthy and this finding suggests that further study on the relationship between culture and trade is needed. It was expected that cultural affinity would facilitate trade, however, the results of this study confirm that the opposite is true. This is likely, however, to be influenced by other (political) factors. Population size, GDP and GDP per capita all represent market size and so it is also not surprising that they demonstrate a positive correlation with trade volume (a larger market will have a greater demand for imports and more productive capacity for exports). However, it is significant to note that population size and GDP have more significant positive correlations with trade volume than commercial institutional membership. This suggests that commercial institutions do not possess the potential to direct (perhaps even divert) trade away from larger markets to smaller ones, thus explaining some of the trade patterns witnessed.

The data analysis conducted here also shows that there is a direct negative correlation between trade volume and MIDs, confirming that trade does have a pacifying effect in the MENA. However, at -.056 (significant at the 0.01 level) this impact is very limited and not particularly encouraging. The rank order of the variables and MIDs from most significant negative correlation to most significant positive correlation is as follows: 1) alliances; 2) cultural affinity; 3) commercial institutional membership; 4) trade congruence; 5) population size; 6) trade volume; 7) GDP (positive); 8) military capabilities (positive); 9) GDP per capita (positive); 10) contiguity; and 11) regime type. Commercial institutional membership ranks third out of eleven variables but trade volume only ranks seventh and has the lowest score for a negative correlation. Increasing economic integration/interaction through trade, therefore, while reducing the occurrence of MIDs does not offer a very compelling policy approach to promoting peace in the region. As with the impact of commercial institutions on trade volume, the test finds that the prevention of MIDs has a more significant correlation with a number of other variables. Cultural affinity (-.302 significant at the 0.01 level) and alliances (-.362 significant at the 0.01 level) both have a much larger impact on preventing MIDs than trade volume. Importantly, however, while trade volume does not have a great impact on reducing MIDs, CIP theory is still relevant 
in terms of informing policy in the MENA. This is because the data analysis shows that engaging in commercial institutions has a clear impact on MIDs: having a direct negative correlation (-.203 significant at the 0.01 level) regardless of the level of trade volume.

These findings mean that promoting domestic economic welfare in MENA states can be supported by commercial institutions if we assume that increased trade volume leads to gains such as increased production, job creation, lower consumer costs and so on. However, governments should not rest all of their hopes on reducing barriers and promoting market integration as commercial institutions do not seem to have increased trade volume significantly so far. Let us now consider what these findings mean for the second policy goal being considered: promoting inter-state cooperation and regional peace. Here, again, contrary to the findings of much of the CIP literature that considers other regions or the global system as a whole (as discussed above), this study finds that MENA governments are not likely to be able to significantly promote peace through encouraging economic integration. The reasons for this are not clear and further investigation is needed into the causes of peace/its absence in the region. This study demonstrates that where economic integration takes place the occurrence of MIDs is only slightly reduced compared to conditions of greater economic disintegration between states. It is possible, however, that as many of the commercial institutions in the MENA are relatively young and are still in the process of being implemented, their effect on trade levels may not yet have had sufficient time to materialize. Furthermore, in order for economic integration to cause peace, decision-makers need to realize and appreciate the benefits of economic interdependence for the pursuit of their interests. This may also need more time to materialize and, therefore, it is possible that in the future, MENAspecific commercial institutions will have a greater positive effect on increasing trade volume, and governments may become more sensitive to the change in economic conditions.

At the same time, if governments do wish to pursue peace and stability in their bilateral and regional relations, the creation of commercial institutions is helpful regardless of the effect on economic interactions. This may be because of the political opportunities that commercial institutions provide to decision makers. As discussed above the finding made by Bearce and Omori (2005) that commercial institutions build trust by regularly bringing high-level state leaders and decision-makers together is supported to an extent by this study. The analysis presented here suggest that, for the MENA, CIP is not necessarily about economic integration, but rather it is about governmental interactions.

\section{Conclusions}

Commercial institutions in the MENA have promoted trade between member-states since 1990, however, the correlation between commercial institutions and trade volume is not very significant. Population and GDP size (market size), and the distance between markets have more significant effects on trade volume. Yet at the same time, economic integration/interaction through trade does have a pacifying effect and reduces the likelihood of MIDs, albeit to a limited extent. This study has found that 
the fundamental assumption posited by CIP theory (that peace can be promoted between states through engagement with commercial institutions) is correct in the case of the MENA. Commercial institutions formed by states in the region do have a pacifying effect, reducing the likelihood of MIDs and thus promoting peace in the region. This effect arises not only from commercial institutions promoting trade, but also through the engagement with commercial institutions themselves - perhaps through a functional spill-over effect. However, the data analyzed in this study is not sufficient to form conclusions on any possible spill-over effect, and further study is needed on this issue.

In conclusion, the first hypothesis tested in this study (that commercial institutions in the MENA promote trade within the region) has been proven to be correct, but with the caveat that this impact is limited. The second hypothesis tested (that higher levels of bilateral trade promote peace by deterring aggression) has also been proven to be correct, but again the effect is limited. While this study demonstrates that there are policy implications for promoting peace in the MENA through reducing MIDs by promoting commercial institutions and economic integration, it also raises some questions that should be pursued in future research. Commercial institutional membership seems to have a more significant impact on promoting peace than levels of economic interaction, yet, we still do not fully understand why this is the case. It could be useful, for example, to investigate if the nature of trade (in terms of the goods and services being traded), and the balance of trade (symmetry/asymmetry) have an impact on the pacifying effect of trade in the region, and what commercial institutions do to state leaders' perceptions of each other.

\section{References}

Abboud, A.R. \& Minow, N. N (2002). Advancing Peace in the Middle East: The Economic Path Out of Conflict. Foreign Affairs 81(5), 14-16.

Abedini, J. \& Péridy, N. (2008). The Greater Arab Free Trade Area (GAFTA): An Estimation of Its Trade Effects. Journal of Economic Integration 23(4), 848-872.

Al-Atrash, H. \& Yousef, T. (2000). Intra-Arab Trade: is it too Little. Washington, DC: IMF.

Angell, N. (1913). The Great Illusion: A Study of the Relation of Military Power to National Advantage. London: Read Books.

Aydin, A. (2008). Choosing Sides: Economic Interdependence and Interstate Disputes. The Journal of Politics 70(4), 1098-1108.

Aydin, A. (2010). The Deterrent Effects of Economic Integration. Journal of Peace Research 47(5), 523-533.

Barbieri, K. (1996). Economic Interdependence: A path to peace or a source of interstate conflict? Journal of Peace Research 33(1), 29-49.

Bearce, D.H. (2003). Grasping the Commercial Institutional Peace. International Studies Quarterly 47(3), 347-370. 
Bearce, D.H. \& Omori, S. (2005). How Do Commercial Institutions Promote Peace? Journal of Peace Research 42(6), 659-678.

Benson, B.V. \& Niou, E.N.S. (2007). Economic Interdependence and Peace: A Game-Theoretic Analysis. Journal of East Asian Studies 7(1), 35-59.

Copeland, D.C. (1996) Economic Interdependence and War: A Theory of Trade Expectations. International Security 20(4), 5-41.

Darrat, A. \& Pennathur, A.K. (2002). Are the Arab Maghreb Countries Really Integratable? Some evidence from the theory of cointegrated systems. Review of Financial Economics 11(2), 79-90.

Davidson, C. (2013). After the Sheiks: The Coming Collapse of the Gulf Monarchies. New York: Oxford University Press.

de Vries Michiel, S. (1990). Interdependence, Cooperation and Conflict: An Empirical Analysis. Journal of Peace Research 27(4), 429-444.

El-Anis, I. (2011). Jordan and the United States: The Political Economy of Trade and Economic Reform in the Middle East. London: I. B. Tauris.

Ekanayake, E. M. \& Ledgerwood, J.R. (2009). An Analysis of the Intra-Regional Trade in the Middle East and North Africa Region. International Journal of Business and Finance Research 3(1), 19-29.

Elkhafif, M., Tagdhisi-Rad, S. \& Elagraa, M. (eds.) (2012). Economic and Trade Policies in the Arab World. Abingdon: Routledge.

Fakhri, M. (2010). Images of the Arab World and Middle East: Debates About Development and Regional Integration. Wisconsin International Law Journal 28(3), 391-429.

Galal, A. \& Hoekman, B. (2003). Arab Economic Integration: Between Hope and Reality. Washington,

DC: Brookings Institution Press.

Gartzke, E., Li, Q. \& Boehmer, C. (2001). Investing in the Peace: Economic Interdependence and International Conflict. International Organization 55(2), 391-438.

Goldsmith, B. (2013). International Trade and The Onset and Escalation of Interstate Conflict: More to Fight About, or More Reasons Not to Fight? Defence \& Peace Economics 24(6), 555-578.

Gross, O. \& Sagi, S. (2000). Regional Trade Arrangements in the Service of Peace in the Middle East. In Bar-El, R, Menipaz, E. \& Benhayoun, G. (eds.), Regional Cooperation in a Global Context. Paris: L'Harmattan, 2000.

Hakimian, H. \& Nugent, J. B. (2005). Trade Policy and Economic Integration in the Middle East and North Africa: Economic Boundaries in Flux. Abingdon: Routledge.

Henwood, D. (1993). Global Economic Integration: The Missing Middle East. Middle East Report 184, $7-8$.

Hoekman, B. \& Messerlin, P. (2002). Harnessing Trade for Development and Growth in the Middle East. Report by the Council on Foreign Relations Study Group on Middle East Trade Options.

Ismael, T., Ismael, J. \& Perry, G. (2015). Government and Politics of the Contemporary Middle East: Continuity and Change. Abingdon: Routledge. 
Kilchevsky, A., Cason, J. \& Wandschneider, K. (2007). Peace and Economic Interdependence in the Middle East. World Economy 30(4), 647-664.

Kim, H.M \& Rousseau, D.L. (2005). The Classical Liberals Were Half Right (or Half Wrong): New Tests of the 'Liberal Peace', 1960-88. Journal of Peace Research 42(5), 523-543.

Konan, D.E. (2003). Alternative Paths to Prosperity: Economic Integration Among Arab Countries. In Galal, A. \& Hoekman, B. (eds.), Arab Economic Integration. Washington, DC: The Brookings Institute. Lopez-Calix, J., Walkenhorst, P. \& Diop, N. (eds.) (2010). Trade Competitiveness of the Middle East and North Africa: Policies for export diversification. Washington, DC: World Bank.

Low, L. \& Salazar, L.C. (2011). The Gulf Cooperation Council: A Rising Power and Lessons for ASEAN. Singapore: Institute of Southeast Asian Studies.

McDonald, P.J. (2004). Peace Through Trade or Free Trade? The Journal of Conflict Resolution 48(4), 547-572.

Momani, B. (2007). A Middle East Free Trade Area: Economic Interdependence and Peace Considered. The World Economy 30(11), 1682-1700.

Ohmae, K. (1994). The Borderless World: Power and Strategy in the Interlinked Economy. New York: HarperCollins.

Oneal, J.R., Oneal, F.H., Maoz, Z. \& Russett, B. (1996). The Liberal Peace: Interdependence, Democracy, and International Conflict, 1950-85. Journal of Peace Research 33(1), 11-28.

Oneal, J.R. \& Russett, B. (199). The Kantian Peace: The Pacific Benefits of Democracy, Interdependence and International Organizations, 1885-1992. World Politics 52(1), 1-37.

Oneal, J.R., Russett, B. \& Berbaum, M.L. (2003). Causes of Peace: Democracy, Interdependence, and International Organizations, 1885-1992. International Studies Quarterly 47(3), 371-393.

Peridy, N. (2005). Toward a Pan-Arab Free Trade Area: Assessing Trade Potential Effects of the Aghadir Agreement. Developing Economies 43(3), 329-345.

Polachek, S. (1992). Conflict and Trade: An economics Approach to Political International Interactions. In Isard, W. \& Anderton, C.H. (eds.), Economics of Arms Reduction and the Peace Process. Amsterdam: North-Holland.

Polachek, S. \& McDonald J. (1992). Strategic Trade and the Incentive for Cooperation. In Chatterji, M. \& Forcey, L.R. (eds.), Disarmament, Economic Conversion and Peace Management. New York: Praeger.

Polachek, S., Robst, J. \& Chang, Y.C. (1999). Liberalism and Interdependence: Extending the TradeConflict Model. Journal of Peace Research 36(4), 405-422.

Reuveny, R. (2001). Bilateral Import, Export, and Conflict/Cooperation Simultaneity. International Studies Quarterly 45(1), 131-158.

Romagnoli, A. \& Mengoni, L. (2009). The Challenge of Economic Integration in the MENA Region: From GAFTA and EU-MFTA to Small Scale Arab Unions. Economic Change and Restructuring 42(1), 69-83. 
Rouis, M. (2012). Regional Economic Integration in the Middle East and North Africa: beyond trade reform. Washington: World Bank.

Strange, S. (1994). States and Markets, $2^{\text {nd }}$ edition. London: Bloomsbury Academic.

Zarouk, J. (2003) The Greater Arab Free Trade Area. In Hoekman, B. \& Zarrouk, J. (eds.), Catching Up With the Competition: Trade Opportunities and Challenges for Arab Countries. Ann Arbor: The University of Michigan Press.

Zineldin, M. (2002). Globalisation, Strategic Co-operation and Economic Integration Among Islamic/Arab Countries. Management Research News 25(4), 35-61. 